Omni-Akuatika, 16 (1): 53 -61, 2020
ISSN: 1858-3873 print / 2476-9347 online
Research Article
journal homepage: http://ojs.omniakuatika.net

\title{
Design a Photobioreactor for Microalgae Cultivation with the IOTs (Internet of Things) System
}

\author{
Ayi Rahmat ${ }^{1^{*}}$, Indra Jaya ${ }^{2}$, Totok Hestirianoto ${ }^{2}$, Dedi Jusadi ${ }^{3}$, Mujizat Kawaroe ${ }^{4}$ \\ ${ }^{1}$ Doctoral Program Student, Study Program of Marine Technology, Faculty of Fisheries and Marine Sciences, IPB \\ University, Campus IPB Dramaga, Bogor, Indonesia \\ ${ }^{2}$ Division of Instrumentation and Marine Robotics, Department of Marine Science and Technology, Faculty of \\ Fisheries and Marine Sciences, IPB University, Campus IPB Dramaga, Bogor, Indonesia \\ ${ }^{3}$ Department of Aquaculture, Faculty of Fisheries and Marine Sciences, IPB University, Campus IPB Dramaga, \\ Bogor, Indonesia \\ ${ }^{4}$ Division of Marine Hydrobiology, Department of Marine Science and Technology, Faculty of Fisheries and \\ Marine Sciences, IPB University, Campus IPB Dramaga, Bogor, Indonesia
}

"Corresponding author: ayi_rachmat@yahoo.com

Received 21 January 2020; Accepted 25 May 2020; Available online 31 May 2020

\begin{abstract}
Internet of Things (IOTs) is an evolution of the concept of internet use that aims to expand the benefits of internet connectivity that is connected continuously with the ability to control remotely (remote control), share data (data sharing), carry out continuous monitoring (real time monitoring) and current (up to date). This research related to the cultivation of microalgae as a source of food and energy of the future, in the design of photobioreactors that are integrated with loT, so that it can be monitored continuously, controlled and used as a model for the development of greater microalgae cultivation technology. Cultivation in this study was a closed system photobioreactor, will produce microalgae that are not contaminated by external contaminants, growth analysis can be done based on the parameters that influence it, including the cultivation room temperature, lighting level (luminance), and the color of water in the photosynthesis process of microalgae, and also control of water circulation. Visualization of controlled parameters includes, temperature parameters, light intensity, water color changes. The observed parameters will be displayed in a graphical user interface (GUI) in real time using the internet. The advantages of this system can see the growth of microalgae in detail over time, and obtained raw data that can be processed for various research purposes.
\end{abstract}

Keywords: microalga cultivations, fotobioreactor, IOTs (Internet of Things)

\begin{abstract}
ABTSRAK
Internet of Things (IOTs) adalah evolusi dari konsep penggunaan internet yang bertujuan untuk memperluas manfaat konektivitas internet yang terhubung secara terus menerus dengan kemampuan untuk mengendalikan jarak jauh (remote control), berbagi data (data sharing), melakukan pemantauan terus menerus (real time monitoring) dan saat ini (up to date). Penelitian ini berkaitan dengan budidaya mikroalga sebagai sumber makanan dan energi masa depan, dan desain photobioreactors yang terintegrasi dengan loT, sehingga dapat dipantau terus menerus, dikendalikan dan digunakan sebagai model untuk pengembangan teknologi budidaya mikroalga yang lebih besar. Kultivasi dalam penelitian ini adalah sistem tertutup photobioreactor, akan menghasilkan mikroalga yang tidak terkontaminasi oleh kontaminan eksternal, analisis pertumbuhan dapat dilakukan berdasarkan parameter yang mempengaruhinya, termasuk suhu ruang budidaya, tingkat pencahayaan (luminance), dan warna dari air dalam proses fotosintesis mikroalga, dan juga kontrol sirkulasi air. Visualisasi parameter terkontrol meliputi, parameter suhu, intensitas cahaya, perubahan warna air. Parameter yang diamati akan ditampilkan dalam antarmuka pengguna grafis (GUI) secara real time menggunakan internet. Keuntungan dari sistem ini dapat melihat pertumbuhan mikroalga secara rinci dari waktu ke waktu, dan memperoleh data mentah yang dapat diproses untuk berbagai keperluan penelitian.
\end{abstract}

Kata Kunci: budidaya mikroalga, photobioreactor, IOT (Internet of Things) 


\section{Introduction}

The development of the global economy requires a large energy supply, this is due to the development of various industries to meet human needs. Currently around $80 \%$ of global energy demand is produced from fossil fuels. However, widespread use of fossil fuels has caused global climate change, environmental pollution, and health problems (Hallenbeck and Benemann, 2002).

Many countries turn their attention to the development of new, renewable energy sources that are clean, and sustainable. Among the various potential renewable energy sources, one of which is biofuel and is in great demand, so it is expected to play an important role in the global energy infrastructure in the future. Biodiesel is one of the most commonly used biofuels, recognized as an ideal source of energy that can be recycled and renewable, thus also the future can be a primary energy source (Chisti, 2007). Commercial biodiesel is currently produced from animal fats, frying oils and vegetable oils (Barnwal and Sharma, 2005), where competition with vegetable oils for agricultural land remains a controversial issue (Mata et al., 2010). As a result, microalgae that can grow quickly and convert solar energy into chemical energy through $\mathrm{CO}_{2}$ fixation in photosynthesis are now considered promising sources of oil to make biodiesel (Mata et al., 2010).

Global warming caused by $\mathrm{CO}_{2}$ emissions has become an important concern in both energy and environmental aspects. Biophysical uptake of $\mathrm{CO}_{2}$ by photosynthetic microalgae is an important $\mathrm{CO}_{2}$ mitigation method from different sources, especially industrial exhaust gases and coal-fired power plants. Previous studies have suggested that industrial exhaust gases that are rich in $\mathrm{CO}_{2}$ can be used to grow large-scale microalgae (Langley et al., 2012). $\mathrm{CO}_{2}$, which is a gas that is easily subjected to changes in shape in the atmosphere, in several studies carried out control of the concentration of $\mathrm{CO}_{2}$ that enters the algae bioreactor system. To be able to monitor the concentration of $\mathrm{CO}_{2}$ in the cultivation system, it is needed an instrumentation system that can control and monitor its presence so that it can be used by microalgae for growth. Closed system photobioreactors are considered as important and high potential photobioreactors because of photosynthetic efficiency and higher biomass productivity, because they are easily controlled and conditioned by their cultivation environment for optimal microalgae growth.

Under suitable culture conditions, some microalgae species are able to accumulate up to $50-70 \%$ oil or lipid per dry weight (Chisti, 2007). Microalgae oil fatty acid profile is very suitable for biodiesel synthesis (Gouveia et al., 2010). The main attraction of using microalgae oil for biodiesel is the extraordinary oil production capacity by microalgae, because it can produce oil up to $58,700 \mathrm{~L}$ per hectare, in this case it can be one or two times higher than other energy plants (Chisti, 2007). However, mass production of microalgal oil faces a number of technical obstacles that make the development of the algae industry currently economically unfeasible. In addition, it is also necessary, but very difficult, to develop cost-effective technologies that enable efficient harvesting of biomass and oil extraction. However, because the production of microalgae is considered a feasible approach to reduce global warming, it is clear that producing oil from microalgae biomass will provide significant benefits, besides fuel. Microalgae is widely known as a raw material for third generation biofuels (Chisti, 2007).

As an alternative raw material for biodiesel production (Kawaroe et al., 2010; Lee and Shen, 2004; Tomaseli, 2004; Sunda et al., 2005) microalgae has the following advantages compared to conventional oil plants such as soybean: 1) microalgae has a simple structure, but photosynthetic efficiency is high with a doubling time of growth of less than 24 hours. Moreover, microalgae can be produced throughout the year (Fon Sing, 2010). Some data in Table 1 shows that microalgae is the only source of biodiesel that has the potential to replace fossil fuels; 2) Abundance of species and biodiversity of microalgae over the climate spectrum and broad geographical areas make seasonal and geographical restrictions less received attention compared to other lipid food ingredients. Microalgae can be processed in fresh water, saltwater lakes with eutrophication, oceans, marginal lands, deserts, etc.; 3) Microalgae can effectively remove nutrients such as nitrogen and phosphorus, and heavy metals from wastewater; 4) Intake of large amounts of carbon microalgae through photosynthesis, for

Tabel 1. Comparison of biodiesel sources

\begin{tabular}{lr}
\hline Food Materials & $\begin{array}{r}\text { Oil Produced } \\
(\text { L.ha }\end{array}$ \\
\hline Corn & 172 \\
Soybean & 446 \\
Canola & 1,190 \\
Jatropha & 1,892 \\
Coconut & 2,689 \\
Oil palm & 5,950 \\
Microalgae (70\% oil in biomass) & 136,900 \\
Microalgae (30\% oil in biomass) & 58,700 \\
\hline
\end{tabular}


example, the efficiency of Chlorella vulgaris $\mathrm{CO}_{2}$ fixation reaches $260 \cdot \mathrm{L}^{-1} \cdot \mathrm{h}^{-1}$ in membrane photobioreactors. Utilization of $\mathrm{CO}_{2}$ from thermal power plants with large-scale microalgae production facilities can reduce many of the greenhouse gas emissions blamed for global warming; 5) Production and use of microalgae biodiesel contribute to near zero clean $\mathrm{CO}_{2}$ and sulfur into the atmosphere; 6) Microalgae can produce a number of valuable products, such as protein, polysaccharides, pigments, animal feed, fertilizers, and so on. In short, microalgae is a source of biomass that is still very little utilized for the production of renewable energy.

As a photosynthetic organism, microalgae can absorb $\mathrm{CO}_{2}$ and synthesize organic compounds, such as lipids, proteins and carbohydrates in large quantities in a short period of time. The traditional method of cultivating microalgae based on the photoautotrophic method has many shortcomings, among which low cell density is a major problem causing low productivity.

Therefore, a significant effort to commercialize microalgae biomass production is to develop a high-density cultivation process. Two approaches were developed including: 1) controlling metabolism; 2) the design of a cultivation system (cultivation system in a bioreactor). The development of electronic technology and the internet makes it possible to control, observe and analyze microalgae cultivation systems with electronic sensors that support cultivation, such as temperature, optical, $\mathrm{pH}$ and DO sensors and supporting actuators to activate fluid circulation as a medium in which microalgae grows.

IOTs were define between 2008 and 2009 according to the Cisco System (Esposito et al., 2017) and decission Support system which worked by Gionino et al. (2018) are used sensory system and actuator are controlled by a microcomputer that is connected to the data transceiver (sender and receiver) system, so that data coming from the cultivation system will be able to be analyzed. GUI system (graphic user interface) is the interface between the user and the system that can be operated locally or through the internet network. Current technological developments by utilizing internet networks that can interact with hardware (hardware) is called IOTs (Internet of Things). In this research, an integrated photobioreactor system with loT (intenet of things) was used to monitor the physical parameters of microalgae cultivation in real time, so that an analysis of the development of microalgae cultivation can be carried out over time. This can be a breakthrough for the supply of microalgae cultivation stock for various derivative needs.

\section{Materials and Methods}

\subsection{Material}

The equipment used and consumables part are shown in Table 2.

\subsection{Methods}

Photobioreactors are assembled using 4 reactors measuring $20 \mathrm{~cm} \times 2 \mathrm{~m} \mathrm{~cm}$ with a height of $80 \mathrm{~cm}$ made of acrylic with a thickness of $5 \mathrm{~mm}$. To stabilize the water temperature, a large chamber filled with water with a length of $90 \mathrm{~cm}$, width $60 \mathrm{~cm}$ and height $50 \mathrm{~cm}$ is used. Photobioreactor control uses a microcomputer as a control base. There are 2 microcomputers used, namely WEMOS D1 which is directly related to the sensor, where the sensor used is a temperature sensor (Dallas DS18B20), amounting to 1 for each reactor, and 1 environment temperature sensor which is placed in a large chamber, so 5 temperature sensors used (Figure 1).

Light sensors (TSL2561 light sensors) and color sensors (RGB sensors TCS3200), are also connected to Wemos D1 so that the number of sensors connected to the WEMOS D1 Microcomputer is 3 pieces, respectively, so for 4 reactors, sensors need 4 temperature sensors, 4 light intensity sensors and 4 color sensors and 1 temperature sensor are inserted in 1 port slot on one of WEMOS D1. To read data from WEMOS $D 1$, Raspberry $\mathrm{Pi}$ is used, as the center of control, because Raspberry $\mathrm{Pi}$ will give commands and receive instructions to the system. Sensor data from Wemos D1 will then be made into a data format that accommodates all sensors and is sent via a Router by Raspberry $\mathrm{Pi}$. so it will be connected to the internet network. Raspberry will also instruct the actuator to continue the control message that comes from the GUI (graphical user interface) from an external device, can use a PC or gadget that is connected to the internet network. So that the hardware can work then the software as its spirit, where with the software the hardware can work according to the command. There are 3 software systems, namely microcontroller programming using Arduino sketch, Raspberry Pi mini PC programming using Python 3.2 and internet programming. Arduino sketch programming is reading data from the three sensors used, namely temperature sensor, brightness sensor and color sensor, then combining the three sensor values into a predetermined data format based on each reactor ID. Programming on a 
Raspberry $\mathrm{Pi}$ mini $\mathrm{PC}$ is divided into several parts, namely first, programming to integrate all data from the four reactors to be sent to the server. Second, the program for automatic control of reactor temperature where the program will read the sensor value on the reactor and the threshold value on the server. If the temperature value is lower than the threshold value specified in the database server, the heater will turn on and vice versa. The third program in the mini PC section is a program for lighting control where the program will continuously check the value in the database server that indicates each lamp is on or off, if there is a difference in value then the program will adjust the on / off of each lamp. Internet programming is done using Apache and PHP web services while for the database using MySQL. There are two main functions in internet programming, namely to display data or graphs of sensor values in realtime and to control lights and heaters.

Table 2. Tools and consumables

\begin{tabular}{|c|c|c|}
\hline No. & Name of Equipment & Function \\
\hline 1 & Computer & $\begin{array}{l}\text { Creating programs, displaying GUls, accessing the } \\
\text { internet, controlling the cultivation system }\end{array}$ \\
\hline 2 & Mini PC/Raspberry Pi & $\begin{array}{l}\text { Local server, to coordinate each sensor data and control } \\
\text { system (relay) and send data to the internet via a GSM } \\
\text { Router }\end{array}$ \\
\hline 3 & Wemos D1 Microcontroller & $\begin{array}{l}\text { Microcontroller for reading sensors and sending sensor } \\
\text { data to Raspberries }\end{array}$ \\
\hline 4 & Router & Raspberry Data Communication with an internet server \\
\hline 5 & Zigsaw & Cutting \\
\hline 6 & Sander & Smoothes \\
\hline 7 & Cutting burrs & Cutting \\
\hline 8 & Solder & Electronic equipment \\
\hline 9 & Hand drill & Making a hole \\
\hline 10 & Others equipment & Ruller, cutter, label, etc. \\
\hline 11 & $\begin{array}{l}\text { Photobioreactor platform material } \\
\text { (paralon } 4 \text { ", Acrilic, Putty Sun Polax, } \\
\text { Tinner, Emery, resin coloring) }\end{array}$ & Make mockups, prints and prints to the desired shape \\
\hline 12 & $\begin{array}{l}\text { Analog Electronic Components } \\
\text { (Resistors, Capacitors) }\end{array}$ & Sensor buffers, signal amplifiers, electronic assembly \\
\hline 13 & Digital electronic components & Electronic assembly \\
\hline 14 & Microcontroller & $\begin{array}{l}\text { The control system in the cultivation system in } \\
\text { photobioreactors }\end{array}$ \\
\hline 15 & Temperature sensor (Dallas) & Get temperature data \\
\hline 16 & Visibility light sensor & Get light intensity data \\
\hline 17 & Colour Sensor (TCS3200) & Get water color data \\
\hline 18 & RTC (real time clock) & Get actual time \\
\hline 19 & Selenoide valve & Water output from the reactor \\
\hline 21 & Aerator & Give aeration to photobioreactors \\
\hline 22 & Cables and accessories & Electronic assembly \\
\hline
\end{tabular}

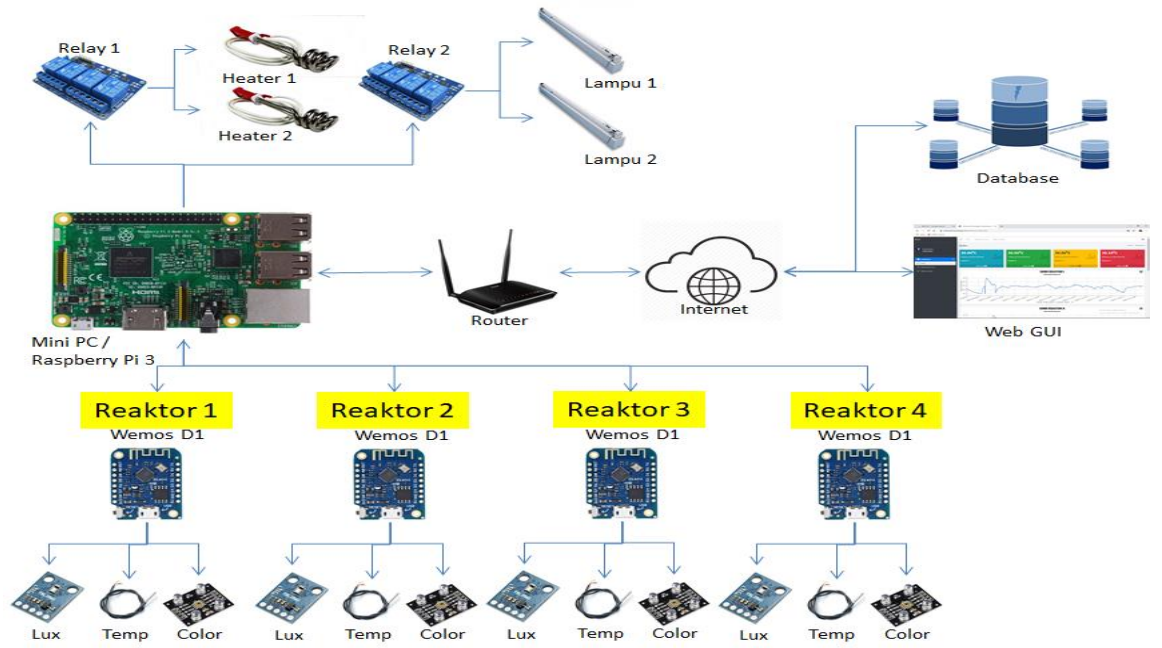

Figure 1. Block diagram of the overall system design 
In accordance with the objectives of the design of the photobioreactor system, that it can carry out continuous monitoring of microalgae cultivation, therefore the system will operate continuously in accordance with the time of cultivation. The limiting parameters to do is to set the desired temperature to be stabilized, in accordance with the conditions of growth for the cultivation of microalgae.

\section{Results and Discussion}

\subsection{Photobioreactor Design}

Recent studies in the field of microalgae in relation to the integration of IOTs are still rarely conducted. According to searches of the literature with Google Scholar and Science Direct, there are 2 studies that are relevant to this research there is Esposito et al. (2017) focusing to a Monitoring, modeling and Decision Support System (DSS) for a Microalgae Production Plant based on the Internet of Things Structure; and Giannino et al. (2018) with focus to predictive Decision Support System (DSS) for a microalgae production plant based on the Internet of Things paradigm.

The loT system presented show capability to produce a reasonable $9 \%$ increase in productivity (Giannino et al. (2018). The performances of the system could be still improved: in fact, up to now, the system do not involve a DSS to help the operator to choose the amount and the timing of the supply of the fertilizing in the pond. The system could be easily afterwards expanded to help the operator to optimize the nutrients supply in the raceway pond in order to increase the productivity of the system. The DSS for the addition of the nutrient could be even connected to the expected productivity derived by the simulations of the model already presented (Esposito et al (2017).

The Monitoring, Modeling and DSS based on Internet of Things Structure presented is able to help almost daily the operator to choose between the better performing Temperature and Irradiance scenarios and is able to warn in advance the operator of the proximity of a danger for the culture even remotely.

This research was focused to closed photobioreactors that different with DSS which focused on masive race way pond to produce microalga for power plant. This photobioreactor consist of 4 reactors, each of which is independently controlled. The control consists of controlling and stabilizing the water temperature of each reactor and the environmental temperature which will affect the temperature of the water in the reactor. An illustration of the design of the built photobioreactor platform can be seen in Figure 2.

The reactor that was built was made from transparent acrylic, where the manufacture was adjusted to the hypothesis that was built, that the cultivated microalgae photosynthesized so that it needed light as a limiting parameter, as well as the cultivation temperature that could be adjusted according to the optimum temperature of life of the microalgae so that cultivation could run well.

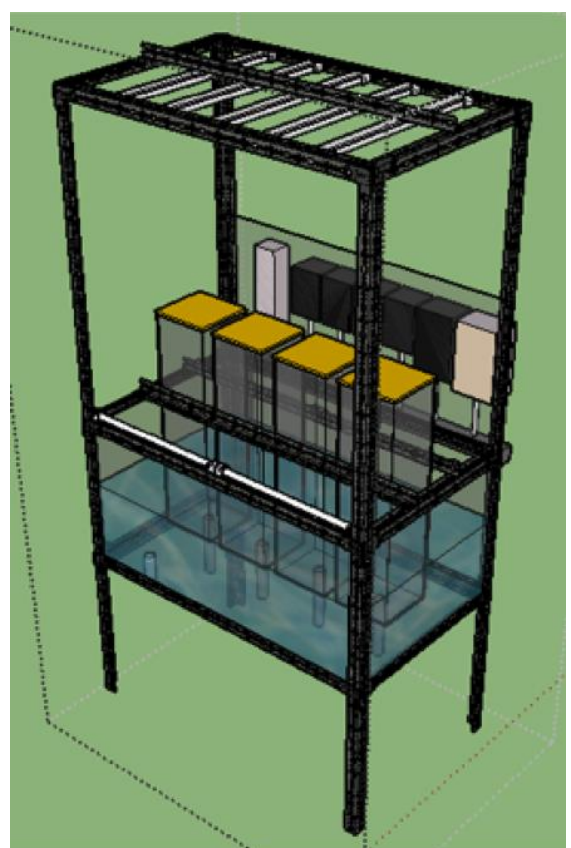

Figure 2. Photobioreactor design sketch

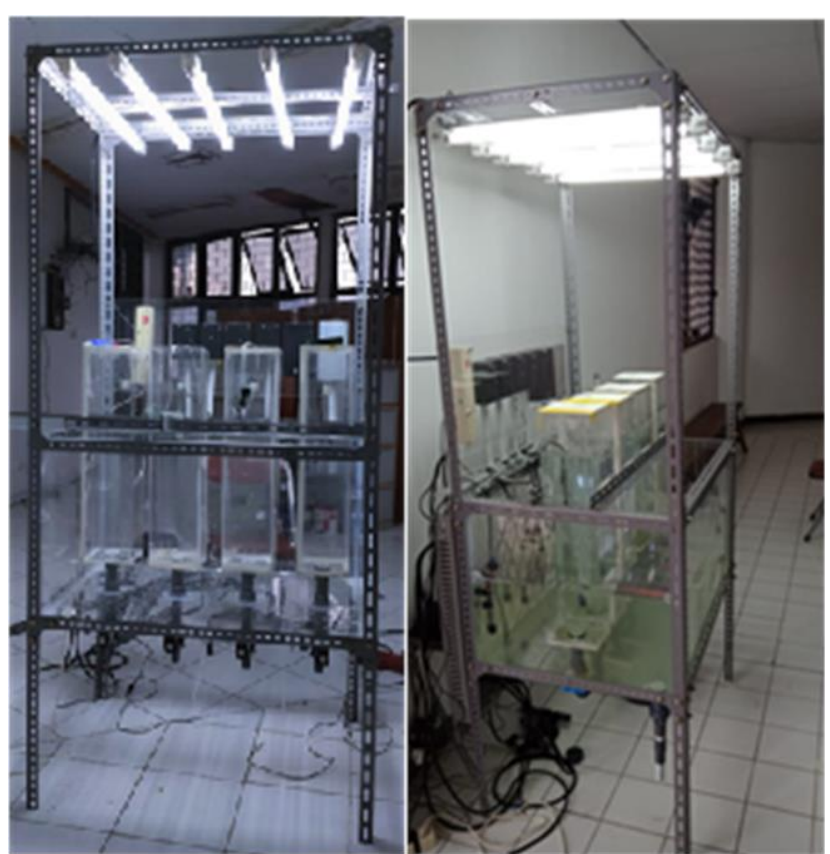

Figure 3. Implementation of photobioreactor design 


\subsection{Photobioreactor Performance}

The built photobioreactor is filled with microalgae with a volume of 10 Liters per reactor so that 4 reactors can accommodate 40 liters of microalgae cultivation. The cultivation process can be carried out by continuously observing the development of microalgae growth from day to day.

The initial process is carried out by entering the microalgae seedlings with the concentration of each reactor is $1: 9$, meaning that 1 Liter concentration of microalgae with 9 Liters of Water, so that the total concentration per reactor is 10 Liters.

Observations were made using a sensor system placed in each reactor consisting of a temperature sensor, light intensity sensor, and color sensor. Data from the sensor will be continuously transmitted to the GUI via the internet network. While the GUI can also carry out the activation order for the actuator contained in the cultivation system such as lights, heaters, and other actuator equipment, because in the relay system connected to the raspberry pi there are 8 slots. This command can be directly responded to by the system and activate as needed.

Cyber-physic interaction is characteristic of a system of IOTs (internet of things) meaning that there is a reciprocal relationship that occurs between physical phenomena observed with a web server which is a control interface with the internet to display all parameters observed in this case using a GUI Figure 4. Is the result of program execution to display and set the temperature point which is the target of stabilization. In the literature that the optimum temperature for cultivation is in the temperature range of $28-32{ }^{\circ} \mathrm{C}$, so that the temperature control is done with a set point of $30^{\circ} \mathrm{C}$.

When the ambient temperature in a large aquarium chamber is lower than the set point temperature, the system will turn on the heater, until the temperature in the reactor is reached, so that the temperature in the reactor will be stable in accordance with the desired temperature.

Measurement data will be stored in a database and can be stored in various data formats, so data processing can be done for various purposes by subsequent researchers.

The data and database display system is displayed in the architecture in Figure 5 as follows:

In the webserver architecture above, the data obtained from the results of data transmission over the internet network will be stored in a database, while the real time data will be displayed directly through the web site https://kultivasimikroalga.com.

The website will display the parameters sensed by the sensor, including the temperature sensor, light intensity sensor and color sensor. The data format sent by the sensor that was previously acquired by Raspberry data must first represent all the sensors used in cultivation, the data format must represent all observed parameters.

// date, time, temperature1, temperature2, temperature3, temperature4, intensity1, intensity2, intensity3, intensity4, red1, red2, red3, red4, green1, green2, green3, green4, blue1, blue2, blue3, blue4 //

From the data format, sensor measurement data will be sent which is then stored in a database. For the appearance of data on the website, it must first be sorted out on the website and displayed in graphical form.

The incoming data will be sorted by the time the data was taken during the cultivation period and will be displayed continuously. The advantage of this system, the data will be

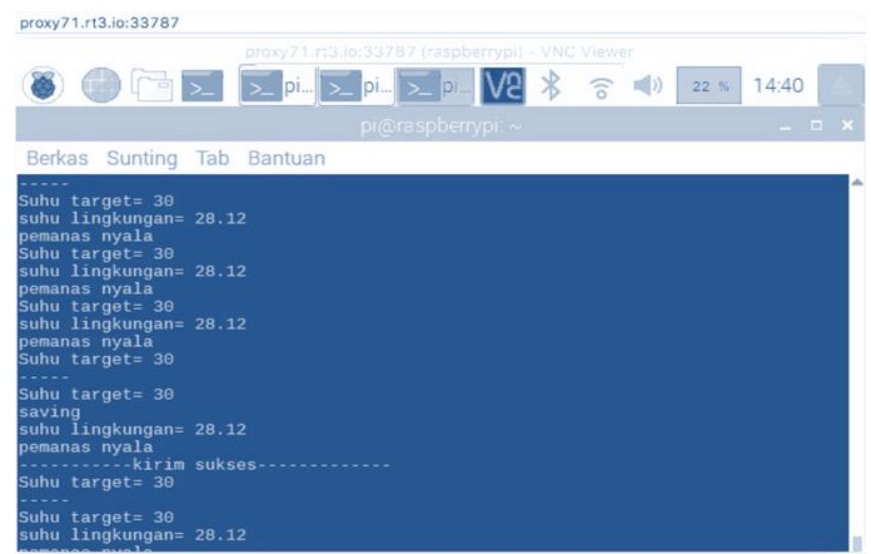

Figure 4. The results of the temperature stabilization program execution (set point $30^{\circ} \mathrm{C}$ )

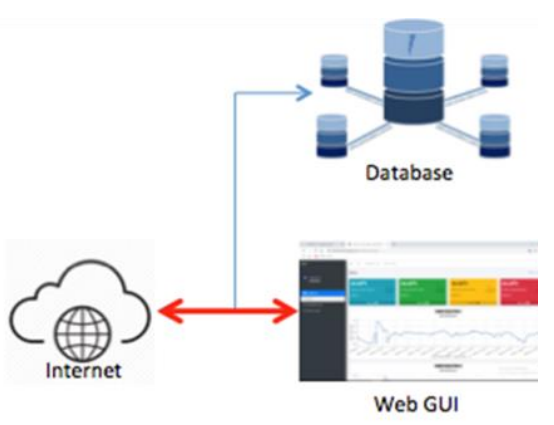

Figure 5. GUI and Database Webserver Architecture 
continuously obtained in accordance with the real conditions in the field and will follow the development of cultivated microalgae. Figure 6 shows the data obtained from time to time and can be seen on the php web server. Data is collected at 30-second intervals and can also be set as needed by following the observed parameter changes. Determination of this observation time interval (time repetition rate, TRR) is very important because it will determine the changes that occur. For example the temperature can change quickly according to the micro climatic conditions around the location of the trial, then the speed of data retrieval and also the time interval of data retrieval is very important to get the accuracy of the data obtained. Likewise with the light intensity sensor, because the development of microalgae to multiply greatly influences the rate of density, the density of microalgae will affect the intensity of light entering the light intensity sensor. The same is true for color sensors, because color changes will be known simultaneously.
Figure 7 shows the system is running which is controlled by a system with temperature stabilization with a set point at $30{ }^{\circ} \mathrm{C}$. The set point is carried out on the PHP web server by editing temp_con as desired, so that it will greatly affect the activation of the actuator (heater) to stabilize the reactor temperature.

Figure 8 shows time series data from time to time for light intensity. On the visible light intensity graph there is a fluctuation of the test results, where during the daytime there is lighting from sunlight which is more dominant so that the intensity increases, then an experiment is carried out by closing the whole reactor with a black tarpaulin, so that there is no lighting from the outside environment, but at the time of the experiments conducted outside the room, a lot of opening and closing of the tarpaulin used as a cover, so recorded by the system, therefore the system has worked well by responding to all activities that occur during the trial process cultivation.

\begin{tabular}{|c|c|c|c|c|c|c|c|c|c|c|c|c|c|c|c|c|}
\hline \multicolumn{16}{|c|}{ 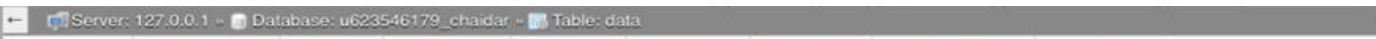 } & \multirow{2}{*}{ औ $=$} \\
\hline Brow & wse & In structi & ture $\quad$ 回 & SaL & \& Sear & 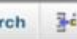 & Insert & $\exists \mathrm{Ex}_{\mathrm{f}}$ & H. Imp & $o_{5}$ & perations & Triggers & & & & \\
\hline$\nabla$ & Id & tanggal & waktu & suhu1 & suhu2 & suhu3 & suhu4 & suhu5 & intensitas1 & intensitas2 & intensitas 3 & intensitas 4 & red1 & red2 & red3 & red4 \\
\hline Delete & 1 & 2019-11-22 & $16: 46: 01$ & 28.19 & 28.25 & 28.06 & 28.19 & 28.00 & 24.00 & 43.00 & 30.00 & 19.00 & 63 & 0 & 49 & 0 \\
\hline (9) Delete & 2 & 2019-11-22 & $17: 06: 45$ & 28.31 & 28.37 & 28.19 & 28.44 & 28.06 & 21.00 & 47.00 & 31.00 & 21.00 & 70 & 0 & 56 & 84 \\
\hline () Delete & 3 & 2019-11-22 & 17:07:53 & 28.31 & 28.37 & 28.12 & 28.37 & 28.06 & 22.00 & 44.00 & 32.00 & 21.00 & 77 & 0 & 61 & 91 \\
\hline$\Theta$ Delete & 4 & 2019-11-22 & $17: 07: 54$ & 28.31 & 28.37 & 28.19 & -127.00 & -127.00 & 22.00 & 48.00 & 31.00 & 19.00 & 87 & 0 & 68 & 88 \\
\hline (ㄱ) Delete & 5 & 2019-11-22 & 17:09:39 & 28.31 & 28.37 & 28.19 & -127.00 & -127.00 & 20.00 & 49.00 & 28.00 & 19.00 & 80 & 0 & 61 & 88 \\
\hline Delete & 6 & 2019-11-22 & $17: 10: 39$ & 28.31 & 28.37 & 28.19 & -127.00 & -127.00 & 20.00 & 49.00 & 28.00 & 19.00 & 80 & 0 & 61 & 88 \\
\hline (e) Delete & 7 & $2019-11-22$ & 17:11:39 & 28.31 & 28.37 & 28.19 & -127.00 & -127.00 & 20.00 & 49.00 & 28.00 & 19.00 & 80 & 0 & 61 & 88 \\
\hline$(\theta)$ Delete & 8 & $2019-11-22$ & 17:12:20 & 28.31 & 28.37 & 28.19 & 28.31 & 28.12 & 22.00 & 50.00 & 30.00 & 19.00 & 70 & 0 & 63 & 88 \\
\hline (9) Delete & 9 & 2019-11-22 & $17: 12: 41$ & 28.31 & 28.37 & 28.19 & 28.31 & 28.12 & 24.00 & 45.00 & 28.00 & 21.00 & 73 & 0 & 58 & 84 \\
\hline Delete & 10 & 2019-11-22 & $17: 13: 20$ & 28.31 & 28.37 & 28.19 & 28.31 & 28.06 & 22.00 & 43.00 & 31.00 & 22.00 & 80 & 0 & 51 & 91 \\
\hline
\end{tabular}

Figure 6. Database on PHP web server

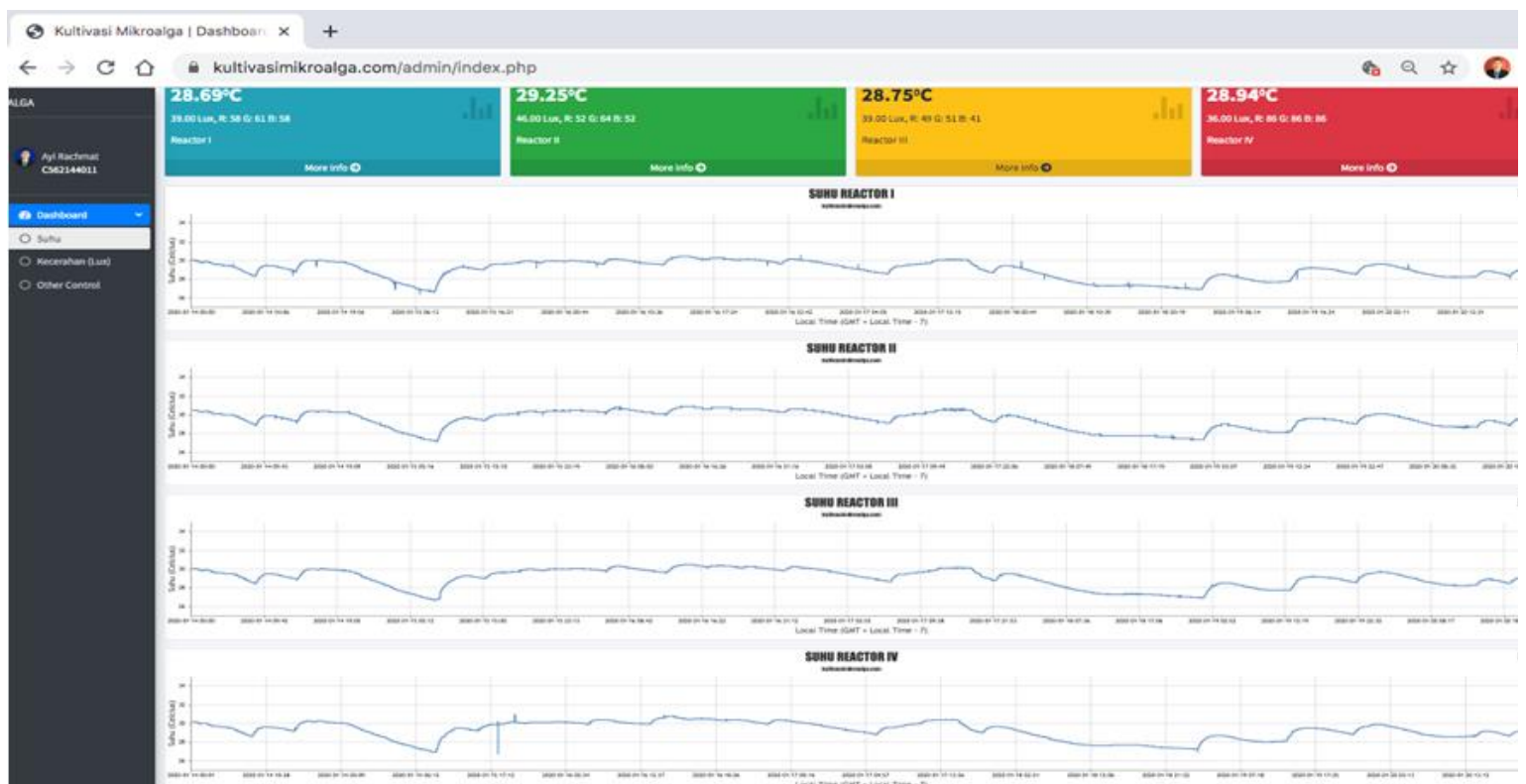

Figure 7. Display from the web https://kultivasimikroalga.com/admin/index.php on a graph display temperature monitored continuously at a set point $30^{\circ} \mathrm{C}$ 


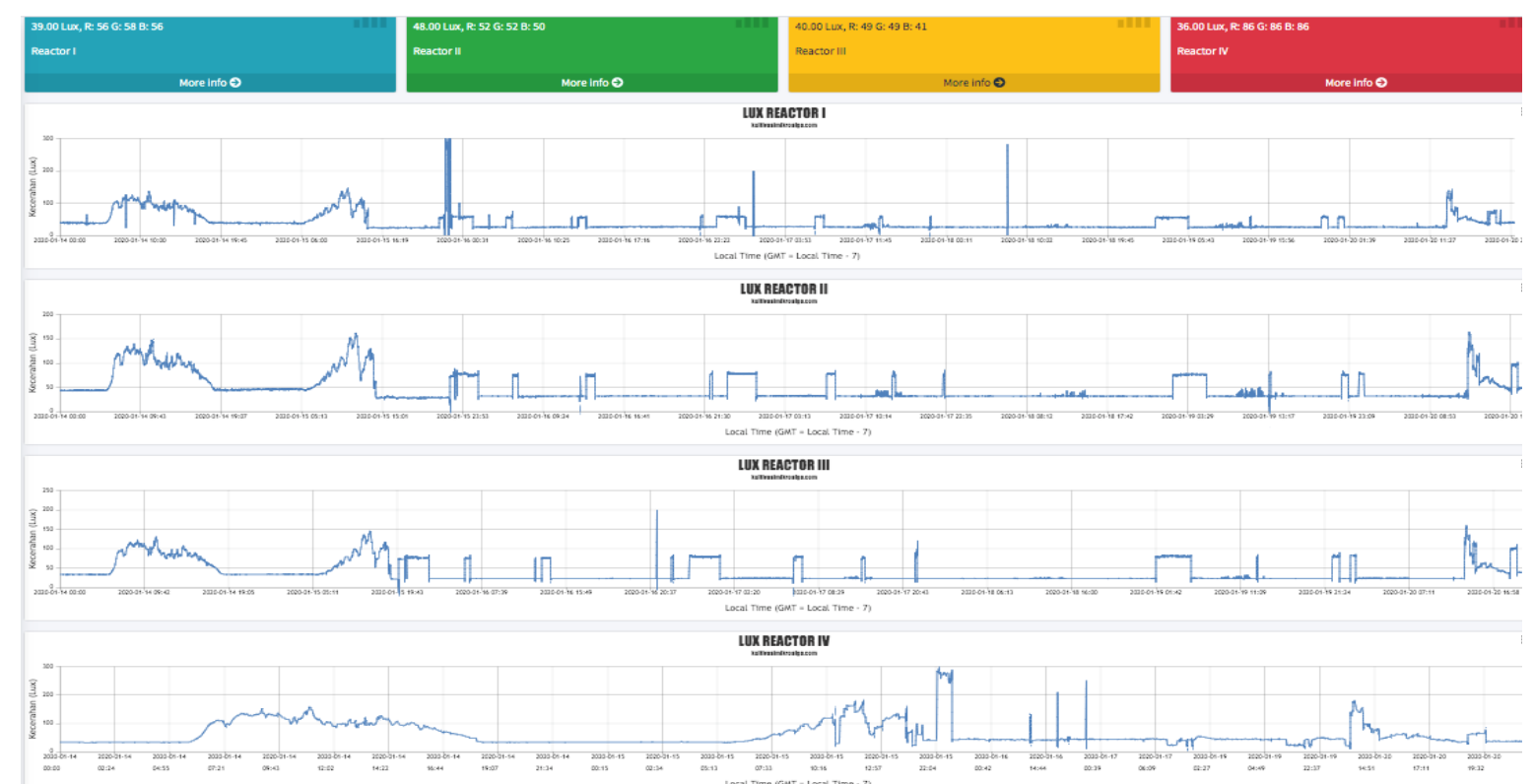

Figure 8. Display from the web https://kultivasimikroalga.com/admin/index.php in the light intensity graph display (lux) which is monitored continuously

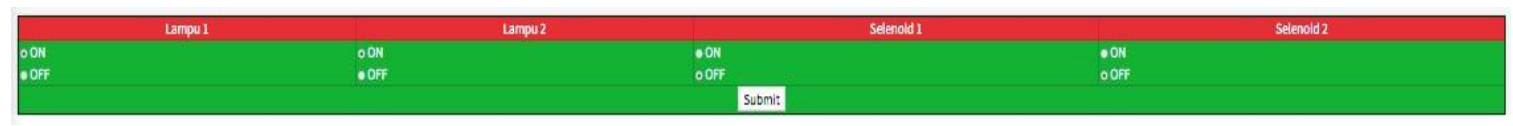

Figure 9. Interaction between GUI and actuator

\section{Conclusion}

From the results of experiments that have been carried out to test the performance of the sensors contained in the photobioreactor, then the following conclusions are obtained: The Temperature, light intensity and the RGB sensor work well on photobioreactors and are able to produce the data needed to analyze the growth and development of microalgae cultivation. To do data logging requires a long time of about 17 days, where the system has never been shut down so that the system is able to work for a long time. IoT on the system has worked well during the cultivation process. Data obtained from temperature, light, and color sensors to determine the growth of microalgae during cultivation time. The loT system can also interact in two directions by controlling the temperature automatically at the desired temperature setting, as well as the GUI (graphical user interface) can control directly on the actuator via a button on the web application. Parameter data during growth can be stored in a database so that it can be reviewed by other researchers as data information in situ. An evaluation of the performance of the integrated photobioreactor system with IOT's (internet of things) has been carried out by observing the microalgae cultivation cycle with three treatments for different concentrations. The system can respond by getting data during the cultivation process.

\section{Acknowledgement}

Special thanks to Laboratory member of Instrumentation and Robotic lab, Mr. M. Iqbal, Chaidar Aji, Dr. Donwill Panggabean, Dr. Wiliandi Setiawan and Dr. Bahdad. Department of Marine Science and Tecnology, Faculty of Fisheries and Marien Science-IPB University.

\section{Refferences}

Barnwal, B.K. and Sharma, M.P. 2005. Prospects of Biodiesel Production from Vegetable Oils in India. Renewable and Sustainable Energy Reviews 9: 363-378.

Chisti, Y. 2007. Biodiesel from Microalgae. Biotechnology Advances 25: 294-306.

Esposito, S., Cafiero, A., Giannino, F., Mazzoleni, S., Diano, M. 2017. A Monitoring, Modeling and Decision Support System (DSS) for a Microalgae Production Plant based on Internet of Things Structure Procedia Computer Science 113: 519-524.

Hallenbeck, P. and Benemann, J. 2002. Biological Hydrogen Production; Fundamentals and Limiting Processes. 
International Journal of Hydrogen Energy 27.

Langley. 2012. Genomic variation in natural populations of Drosophila melanogaster. Genetics 192(2): 533-98.

Mata. 2010. Microalgae for biodiesel production and other applications: A review. Renewable and Sustainable Energy Reviews 14(1): 217-232.

Fon Sing, M. S. D. 2010. Strain Selection and Outdoor Cultivation of Halophilic Microalgae with Potential for Large Scale Biodiesel Production. Thesis for Doctor Degree. Murdoch University.

Giannino, F., Esposito, S., Diano, M., Cuomo, S., Toraldo, G. 2018. A predictive Decision Support System (DSS) for a microalgae production plant based on Internet of Things paradigm. Concurrency Computat 30(15):1 -6

Gouveia, L., Marques, A. E., Sausa, J.M., Bandarra, N. M. 2010. Microalgae - source of natural bioactive molecules as functional ingredients. Food Sci Technol Bull: Funct Foods 7(2): 21-37.

Kawaroe, M., Prartono, P., Sunuddin, A., Sari, D. W. 2010. Mikroalga: potensi dan pemanfaatannya untuk produksi bio bahan bakar. IPB Press, Bogor.

Lee, Y. K. and Shen, H. 2004. Basic Culturing Techniques. In: Handbook of Microalgal Culture: Biotechnology and Applied Phycology (eds. Amos Richmond). Blackwell Science: $40-54$.

Sunda, W., Price, N., Morel, F. M. M. 2005. "Trace Metal Ion Buffers And Their Use In Culture Studies". In Algal Culturing Techniques, 35-63. Algal Culturing Techniques. Burlington, MA: Academic Press.

Tomaselli, L. 2004. The Microalgal Cell. In: Handbook of Microalgal Culture: Biotechnology and Applied Phycology (eds. Amos Richmond). Blackwell Science: 3-17. 